\title{
Transactivation of HER2 by vasoactive intestinal peptide in experimental prostate cancer: Antagonistic action of an analog of growth-hormone-releasing hormone
}

\author{
SANDRA SOTOMAYOR ${ }^{1}$, MARÍA J. CARMENA ${ }^{1}$, ANDREW V. SCHALLY ${ }^{2,3}$, JOZSEF L. VARGA ${ }^{2,3}$, \\ MANUEL SÁNCHEZ-CHAPADO ${ }^{4,5}$, JUAN C. PRIETO ${ }^{1}$ and ANA M. BAJO ${ }^{1}$ \\ ${ }^{1}$ Molecular Neuroendocrinology Unit, Department of Biochemistry and Molecular Biology, University of Alcalá, \\ 28871 Alcalá de Henares, Spain; ${ }^{2}$ Veterans Administration Medical Center and South Florida \\ Veterans Affairs Foundation for Research and Education, Miami, FL 33125; ${ }^{3}$ University of Miami, \\ School of Medicine, Miami, FL 33136, USA; ${ }^{4}$ Department of Surgery, University of Alcalá, and \\ ${ }^{5}$ Department of Urology, Príncipe de Asturias Hospital, 28871 Alcalá de Henares, Spain
}

Received May 29, 2007; Accepted July 2, 2007

\begin{abstract}
Receptors for vasoactive intestinal peptide (VIP) and the human epidermal growth factor family of tyrosine kinase receptors (HER) are potent promoters of cell proliferation, survival, migration, adhesion and differentiation in prostate cancer cell lines. In this study, we analyzed the cross-talk between both classes of receptors through the regulation of HER2 transactivation and expression by VIP. Three growth-hormone-releasing hormone analogs endowed with antagonistic activity for VIP receptors (JV-1-51, -52, and -53) abrogated the autocrine/paracrine stimuli of VIP on androgen-independent PC3 cells in the absence or the presence of $10 \%$ fetal bovine serum. Semiquantitative and real-time quantitative RT-PCR together with Western blotting showed increased expression levels of both mRNA and proteins for HER2 and HER3 in PC3 and androgen-dependent LNCaP prostate cancer cells as compared to non-neoplastic RWPE-1 cells. VIP (100 nM) stimulated the expression levels of both HER2 and HER3 in PC3 cells in a time-dependent manner. Whereas these effects were relatively slow, VIP rapidly (0.5 min) increased HER2 tyrosine phosphorylation. This pattern of HER transactivation was blocked by H89, a protein kinase A (PKA) inhibitor, as well as by the specific VIP antagonist JV-1-53, indicating the involvement of VIP receptors and PKA activity in phosphorylated HER2 formation. These findings support the merit of further studies on the potential usefulness of VIP receptor antagonists and both
\end{abstract}

Correspondence to: Professor Juan C. Prieto, Molecular Neuroendocrinology Unit, Department of Biochemistry and Molecular Biology, Alcalá University, 28871 Alcalá de Henares, Spain E-mail: juancarlos.prieto@uah.es

Key words: vasoactive intestinal peptide receptors, HER2, HER3, growth-hormone-releasing hormone analogs, prostate cancer
HER 2 antibodies and tyrosine kinase inhibitors for prostate cancer therapy.

\section{Introduction}

Prostate cancer is the second leading cause of cancer-related deaths among men in the Western world (1). It presents as a heterogeneous and multi-stage disease, both at the clinical and histological level. In spite of major improvements in diagnosis, including screening for serum prostate specific antigen (PSA), many prostate cancers are detected at an advanced stage with no possibility of cure by radical prostatectomy (2). Because approximately $70 \%$ of prostate cancers are androgen-dependent at the time of diagnosis, the preferred treatment of advanced prostate cancer is androgen ablation. However, after an initial response and a period of remission, most patients show a relapse with ultimate progression to androgen-independent prostate cancer, for which the prognosis is very poor $(2,3)$. The mechanisms responsible for the loss of androgen dependence are not fully understood. Nevertheless, an active investigation on the role of neuropeptides, neuroendocrine cells and growth factors in the progression of prostate cancer should lead to the development of novel therapies $(3,4)$.

Vasoactive intestinal peptide (VIP) is a pleiotropic neuropeptide that behaves as a potent vasodilator. VIP stimulates prostatic secretion, inhibits muscle contraction, and increases the proliferation of prostatic epithelial cells in culture (5). VIP is also known to increase PSA secretion (6) as well as vascular endothelial growth factor (VEGF) expression and neuroendocrine differentiation in human prostate cancer cell lines $(7,8)$. Furthermore, this neuropeptide stimulates the invasive capacity of prostate cancer cells and protects them from apoptosis (9-11). The biological effects of VIP are mediated by two membrane receptors $\mathrm{VPAC}_{1}$ and $\mathrm{VPAC}_{2}$, which are G-protein coupled receptors (GPCRs) widely expressed in many tissues $(12,13)$ including normal and malignant prostate gland $(4,14)$ as well as prostate cancer cell lines $(7,15)$. Interaction of VIP with these receptors initiates a 
set of events which lead to the activation of protein kinase A (PKA) and phosphorylation of transcriptional factors for specific genes through cAMP response element binding protein (CREB), as well as the activation of the phosphoinositide 3-kinase (PI3-K) and mitogen-activated protein kinase (MAPK)/extracellular signal-regulated kinase (ERK) and MAPK kinase (MEK1/2) systems $(4,9,16-18)$. Interestingly, VIP and growth-hormone-releasing hormone (GHRH) show structural similarity as well as considerable homology between their receptor proteins (19). Two GHRH analogs, JV-1-51 and JV-1-52, have been synthesized that present reduced antagonistic activities on GHRH receptors and increased antagonistic properties on $\mathrm{VPAC}_{1}$ and $\mathrm{VPAC}_{2}$ receptors compared with their parent compounds, as well as the potent antagonist of $\mathrm{VPAC}_{1}$ and $\mathrm{VPAC}_{2}$ receptors, JV-1-53, that is devoid of antagonistic activity on GHRH receptors $(19,20)$. The abrogation of the autocrine/paracrine mitogenic activity of VIP by these antagonists might be of potential value for prostate cancer therapy (21).

The human epidermal growth factor receptor (ErbB/HER) family is comprised of four homologous receptors: EGFR (HER1/ErbB1), HER2/ErbB2, HER3/ErbB3 and HER4/ ErbB4. These receptors are composed of an extracellular binding domain, a transmembrane lipophilic segment, and an intracellular protein tyrosine kinase (TK) domain that is absent in HER3 (22). After ligand binding, HER receptors become activated by dimerization between two identical (homodimerization) or different (heterodimerization) receptors of the same family $(23,24)$. After receptor dimerization, activation of the intrinsic protein kinase activity and tyrosine autophosphorylation occur, recruiting and phosphorylating several intracellular substrates involving the Ras-Raf-MAPK, PI3k-Akt, and other signaling pathways that regulate multiple biological processes including apoptosis and cellular proliferation $(25,26)$. HER2 is a unique member of the HER family in that it does not bind any of the known ligands but it is the preferred heterodimeric partner for the other ErbB/HER receptors. The overexpression and the heterodimerization via ligand binding or non ligand-dependent receptor dimerization, promote tumorigenesis through cell proliferation, survival, migration, adhesion and differentiation (27). Comparison of all receptor combinations revealed that heterodimerization of the ligandless HER2 with the kinase-inactive HER3 provides the most potent mitogenic and angiogenic signals $(28,29)$. Among the members of the HER/ErbB family, HER 1 and HER2 in particular play an important role in the development and progression of various tumors, including prostate cancer $(30,31)$. Many studies have been dedicated to HER2 which activates the androgen receptor and promotes androgenindependent survival and growth of prostate cancer cells (32-35). Interestingly, it has been shown that several agonists of GPCR have the capability to transactivate EGF receptors and thereby recruit associated effector signaling pathways $(36,37)$. In this context, VIP (a GPCR agonist) stimulates HER1 tyrosine phosphorylation through an elevation in intracellular cAMP and activation of PKA in colonic epithelial T84 cells (37).

The present study was undertaken with the main aim of determining the link between VIP receptors and HER2 by means of VIP-induced HER2 transactivation in prostate cancer.
Mimicking tumor progression, non-neoplastic RWPE-1 cells as well as androgen-dependent $\mathrm{LNCaP}$ and independent PC3 cancer cell lines were analyzed for the expression of mRNAs for HER2 and HER3, and HER proteins. Furthermore, the more aggressive cell line, PC3, was used to study the antiproliferative effects of VPAC receptor antagonists (JV-1-51, -52 and -53 ), the effect of VIP on HER2 and HER3 expression, as well as the transactivation of HER 2 by VIP and its blocking by inhibition of VIP signaling. This approach was considered to be useful for the evaluation of the potential therapeutic value of VIP antagonists combined with inhibitors of HER2 signaling for treatment of advanced prostate cancer.

\section{Materials and methods}

Reagents. VIP was purchased from NeoMPS (Strasbourg, France). Chemicals for sodium dodecyl sulphate-polyacrylamide gel electrophoresis (SDS-PAGE), and monoclonal anti- $\beta$-tubulin were obtained from Sigma (St. Louis, MO) and $\beta$-actin was purchased from Calbiochem (Darmstadt, Germany). Protein markers for SDS-PAGE were from Bio-Rad (Hercules, CA, USA). The antisera specific for HER2 and HER3 were obtained from Santa Cruz Biotechnology (Santa Cruz, CA) and that for phospho-HER2-Tyr1248 (HER2-P) was acquired from Upstate (Lake Placid, NY). The synthesis of the human GHRH analogs JV-1-51, JV-1-52 and JV-1-53 was previously described $(19,20)$.

Cell lines. Epithelial human prostate non-neoplastic (RWPE-1), androgen-dependent (LNCaP), and androgen-independent (PC3) prostate carcinoma cell lines, which exhibit different features of prostate cancer progression, were used in receptor expression analysis. Other studies were performed in PC3 cells. The three cell lines were obtained from the American Type Culture Collection (Manassas, VA). RWPE-1 cells were maintained in complete keratinocyte serum-free medium (K-SFM) containing $50 \mu \mathrm{g} / \mathrm{ml}$ bovine pituitary extract and $5 \mathrm{ng} / \mathrm{ml}$ EGF. LNCaP and PC-3 cells were cultured in RPMI1640 medium (Life Technologies, Barcelona, Spain) supplemented with $1 \%$ antibiotic/antimycotic and $10 \%$ fetal bovine serum (FBS). The cells were grown at $37^{\circ} \mathrm{C}$ in a humidified atmosphere containing $95 \%$ air $/ 5 \%$ carbon dioxide and split weekly with $0.25 \%$ trypsin/ $0.2 \%$ EDTA. All culture media components were purchased from Invitrogen (Barcelona, Spain).

Cell proliferation assay. For all experiments, PC-3 cells were grown to $70-80 \%$ confluence, harvested by use of trypsin/ EDTA solution and seeded at low concentration $(50,000$ cells per well) in 24-well plates for $24 \mathrm{~h}$. The culture medium was removed and replaced with RPMI-1640 medium containing $1 \%$ antibiotic/antimycotic and $0 \%$ FBS for $24 \mathrm{~h}$. After the deprivation, cells were stimulated for $24 \mathrm{~h}$ with $100 \mathrm{nM}$ VIP and/or $300 \mathrm{nM}$ antagonists JV-1-51, JV-1-52 or JV-1-53. Cell growth was determined by tetrazolium assay, which measures the reduction of substrate MTT [3-(4,5-dimethylthiazol-2-yl)2,5-diphenyltetrazolium bromide] to a dark blue formazan product by mitochondrial dehydrogenases in living cells. Thereafter, MTT (5 mg/ml) (Sigma) was added to each well and incubated for $3 \mathrm{~h}$ at $37^{\circ} \mathrm{C}$ in darkness. The medium was 
replaced and the precipitate dark blue formazan was dissolved with $0.2 \mathrm{~N} \mathrm{HCl}$ in isopropanol. Then, absorbance was read at $570 \mathrm{~nm}$ in the plate reader (ELX 800, Bio-Tek Instruments, Winooski, VT). Results were calculated as the relative percentage of absorbance compared with control cells.

RNA extraction and reverse transcription polymerase chain reaction $(R T-P C R)$. Cells $\left(1.5 \times 10^{6}\right.$ in $100-\mathrm{mm}^{2}$ cell culture dishes) were stimulated with $100 \mathrm{nM}$ VIP for $15,30,45$, and 60 min. Total RNA was extracted from cells by using TRIR reagent (Biotech Labs, Houston, TX), according to the manufacturer's instructions. Two $\mu \mathrm{g}$ of total RNA was reversetranscribed into cDNA by M-MLV reverse transcriptase, according to the manufacturer's guidelines (Life Technologies, Barcelona, Spain). In order to rule out genomic DNA contamination the RT was also performed without reverse transcriptase. Primers were chosen with the assistance of the computer program Primer Express (Perkin-Elmer Applied Biosystems, Foster City, CA) (Table I). The number of cycles was determined in preliminary experiments to be within the exponential range of PCR amplification. Negative controls with water instead of cDNA were run in parallel to exclude genomic DNA contamination. PCR conditions were denaturation at $94^{\circ} \mathrm{C}$ for $5 \mathrm{~min}$, followed by $94^{\circ} \mathrm{C}$ for $1 \mathrm{~min}$, $60^{\circ} \mathrm{C}$ for $1 \mathrm{~min}, 72^{\circ} \mathrm{C}$ for $1 \mathrm{~min}$ by different cycles (Table I), and then a final cycle of $10 \mathrm{~min}$ at $72^{\circ} \mathrm{C}$. PCR products were subjected to electrophoresis on a $2 \%$ agarose gel, stained with ethidium bromide and visualized under UV light. Bands of PCR-amplified products were scanned and analyzed semiquantitatively, using an Imaging System (Gel Doc $^{\text {TM }}$ XR, Bio-Rad, Madrid, Spain). All the experiments were repeated at least three times and similar results were obtained. The mRNA levels of HER2 and HER3 genes were normalized versus the corresponding levels of $\beta$-actin. The PCR products were purified by a gel extraction kit (Qiagen, Hilden, Germany), and sequenced by an ABI 377 sequencing machine (Applied Biosystems). The sequences were compared with the GenBank database using BLAST analysis (http:// www.ncbi.nlm.nih.gov/blast/bl2seq/wblast2.cgi).

Single-step real-time quantitative RT-PCR. Real-time quantitative RT-PCR analysis was carried out using $90 \mathrm{ng}$ of RNA for each sample and SYBR-Green PCR master mix (Applied Biosystems) in one-step RT-PCR protocol according to the manufacturer's instructions. The thermal cycling conditions were $30 \mathrm{~min}$ at $48^{\circ} \mathrm{C}$ for RT and $10 \mathrm{~min}$ at $95^{\circ} \mathrm{C}$ to activate MultiScribe ${ }^{\mathrm{TM}}$ reverse transcriptase, followed by 40 cycles of $95^{\circ} \mathrm{C}$ for $15 \mathrm{sec}$ and $60^{\circ} \mathrm{C}$ for $1 \mathrm{~min}$. The PCR amplicon region for HER 2 and HER3 was obtained. The relative quantification was normalized to $B$-actin. PCR reaction was carried out using ABI-Prism 7000 SDS (PerkinElmer Applied Biosystems). Results of real-time PCR were represented as $\mathrm{Ct}$ values, where $\mathrm{Ct}$ was defined as the threshold cycle number at which product is first detected by fluorescence. The amount of target (HER2 and HER3) was normalized to an endogenous reference, the housekeeping gene for $\beta$-actin. $\Delta \mathrm{Ct}$ was the difference in $\mathrm{Ct}$ values derived from the studied genes in each sample assayed and the $\beta$-actin gene. $\Delta \Delta \mathrm{Ct}$ represented the difference between the paired samples. The $\mathrm{n}$-fold differential ratio was expressed as $2^{-\Delta \Lambda \mathrm{Ct}}(38)$.
Table I. Oligonucleotide primers used in semiquantitative and quantitative RT-PCR analysis for HER2, HER3, and B-actin expression in human prostate RWPE-1, LNCaP and PC3 cells.

\begin{tabular}{lll}
\hline mRNA Primer & Sequence $\left(5^{\prime} \rightarrow 3^{\prime}\right)$ & $\begin{array}{l}\text { Product } \\
\text { size }(b p)\end{array}$
\end{tabular}

\begin{tabular}{llll}
\hline HER2 & $\begin{array}{l}\text { sense } \\
\text { antisense }\end{array}$ & $\begin{array}{l}\text { CTC ACC TAC CTG CCC ACC AAT } \\
\text { HER3 } 3\end{array}$ & 101 \\
& $\begin{array}{l}\text { sense } \\
\text { antisense }\end{array}$ & CTG GGA CTC GTT CCC CAT CAC CAC CT & \\
B-actin & sense & AGA AGG ATT CCT ATG TGG GCG & 102 \\
& antisense & CAT GTC GTC CCA GTT GGT GAC & \\
\hline
\end{tabular}

Primers were chosen with the assistance of the computer program Primer Express (Perkin-Elmer Applied Biosystems).

Immunodetection of ErbB/HER family members. Cells were washed once with ice-cold PBS and then scraped into icecold PBS. Afterwards, cells were treated with lysis buffer [25 mM Triethanolamine ( $\mathrm{pH} 7.4$ ), $150 \mathrm{mM} \mathrm{NaCl}, 1 \%$ (v/v) Triton X-100, $1 \%$ (v/v) Nonidet P-40 (NP-40), $30 \mathrm{mM} \mathrm{NaF}$, 5 mM EDTA, $1 \mathrm{mM}$ dithiothreitol (DTT), 0.1\% SDS, $1 \mathrm{mM}$ $\mathrm{Na}_{3} \mathrm{VO}_{4}, 2 \mathrm{mM}$ phenylmethylsulfonyl fluoride (PMSF), $10 \mu \mathrm{g}$ aprotinin, $10 \mu \mathrm{g}$ leupeptin, and $10 \mu \mathrm{g}$ pepstatin]. Protein content was measured by the Bradford assay using bovine serum albumin as standard. Protein (30-60 $\mu \mathrm{g})$ from cell lysates was solubilized in $50 \mathrm{mM}$ Tris- $\mathrm{HCl}$ buffer ( $\mathrm{pH}$ 6.8) containing $10 \%$ (v/v) glycerol, $3 \%(\mathrm{w} / \mathrm{v})$ SDS, $0.01 \%$ bromophenol blue, and $0.7 \mathrm{M} \mathrm{B}$-mercaptoethanol and then heated for $5 \mathrm{~min}$. Proteins were resolved on a $8 \%$ SDS-PAGE and then transferred to nitrocellulose sheets (Hoeffer, San Francisco, CA). The nitrocellulose sheets were soaked in Tris-buffered saline (TBS) containing $2 \mathrm{mM}$ Tris (pH 7.6) and $0.8 \% \mathrm{NaCl}$ (or PBS for HER2-P). Excess protein-binding sites were saturated with TBS or PBS containing $0.1 \%$ Tween-20 and 5\% non-fat dried milk. The blotted membranes were incubated for $2 \mathrm{~h}$ with rabbit polyclonal antihuman antibodies: HER2, HER3, and HER2-P at 1:500, 1:2,000, and 1:4,000, respectively. Mouse monoclonal antihuman antibodies, $\beta$-actin and $\beta$-tubulin $(1: 7,000$ and 1:30,000, respectively), were used as loading controls. The bands were analyzed with the imaging densitometer as above, and the relative protein levels were normalized versus the corresponding levels of $\beta$-tubulin or $\beta$-actin.

Statistical analyses. Data are expressed as the means \pm SE. Statistical analyses were performed using the Student's twotailed t-test. All P-values are based on two-sided hypothesis testing. $\mathrm{P}<0.05$ was considered to be significant.

\section{Results}

Effects of VIP and VIP antagonists on proliferation in prostate cancer PC3 cells. We studied the effects of GHRH analogs JV-1-51, -52 and -53 on the proliferation of androgenindependent PC3 that represent advanced prostate cancer (Fig. 1). In both the absence or the presence of $10 \%$ FBS, 

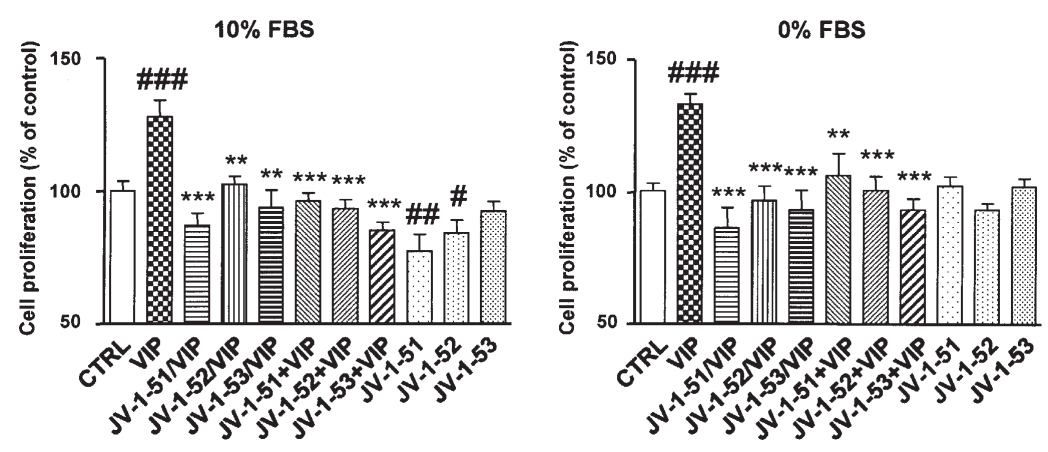

Figure 1. Effects of JV-1-51, -52 and -53 GHRH analogs on the proliferation of human prostate cancer androgen-independent PC 3 cells. In both the absence and the presence of $10 \%$ FBS, cells were treated for $24 \mathrm{~h}$ with $100 \mathrm{nM}$ VIP and/or $300 \mathrm{nM}$ antagonists JV-1-51, JV-1-52 or JV-1-53. The three GHRH analogs were added $30 \mathrm{~min}$ before (JV-1/VIP) or simultaneously (JV-1+VIP) with VIP. Cell growth was determined by the tetrazolium assay and the results were calculated as the relative percentage of those for control cells. Values are means $\pm \mathrm{SE} .{ }^{\#} \mathrm{P}<0.05,{ }^{\# \#} \mathrm{P}<0.01,{ }^{\# \# \#} \mathrm{P}<0.001$ versus control; ${ }^{* *} \mathrm{P}<0.01$, ${ }^{* * *} \mathrm{P}<0.001$ versus VIP $(\mathrm{n}=3)$.

(A)

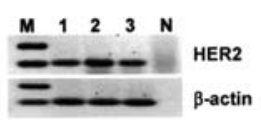

(B)
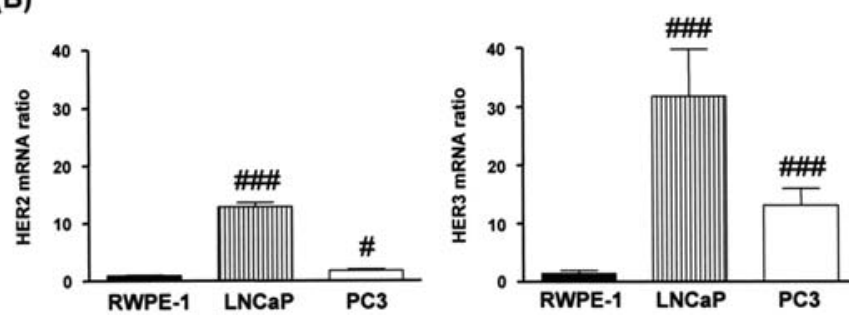

Figure 2. (A) Expression of mRNAs for HER2 and HER3 in RWPE-1 (lane 1), LNCaP (lane 2), and PC-3 (lane 3) human prostate cell lines by semiquantitative RT-PCR. All preparations were normalized according to the expression of mRNA for $\mathrm{B}$-actin. PCRs yielded products of the expected size of $101 \mathrm{bp}$ for HER2 and HER3, and $102 \mathrm{bp}$ for $\beta$-actin. M, 100-bp molecular DNA marker; N, negative control for PCR. (B) Real-time RT-PCR quantification of mRNAs for HER2 and HER3 in RWPE-1, LNCaP and PC3 cells. The $B$-actin transcript was analyzed as a control. Data in each bar are means \pm SE. ${ }^{\#} \mathrm{P}<0.05,{ }^{\# \#} \mathrm{P}<0.001$ versus $\mathrm{RWPE}-1$ cells $(\mathrm{n}=3)$.

VIP stimulated cell proliferation and the three GHRH analogs completely inhibited VIP's effect when added 30 min before or simultaneously with the neuropeptide. When incubated alone with the cells, JV-1-51 and -52, but not JV-1-53, exhibited an antiproliferative effect in the presence of $10 \%$ FBS whereas all three peptides were ineffective in the absence of serum.

Expression of HER2 and HER3 $m R N A s$ and proteins in prostate non-neoplastic and cancer cell lines. Prior to the study of the effect of VIP upon expression and activation of HER, we determined the levels of mRNA and protein for HER 2 and HER 3 throughout cancer progression. For this purpose, total RNA was extracted from non-neoplastic RWPE-1 and cancerous LNCaP and PC3 cells and subjected to both semiquantitative RT-PCR and single-step real-time quantitative RT-PCR. As shown in Fig. 2, HER2 and HER3 mRNAs were detected in the three cell lines, the levels being low in control RWPE-1 cells and increased in cancer cells, and exhibiting the highest values in androgen-dependent $\mathrm{LNCaP}$ cells as compared to androgen-independent PC 3 cells.
(A)

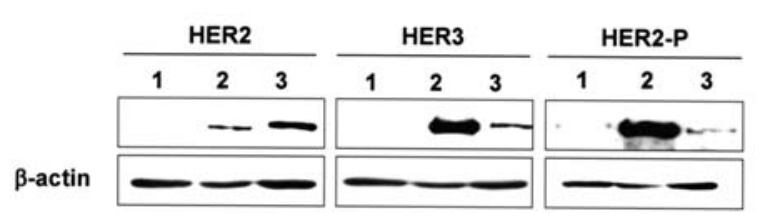

(B)

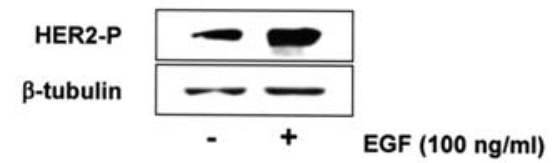

Figure 3. (A) Expression of HER2, HER3, and phosphorylated HER2 (HER2-P) proteins in RWPE-1 (lane 1), LNCaP (lane 2), and PC3 (lane 3) human prostate cell lines. After preparation of cell lysates, Western blotting using antibodies to HER proteins and $\beta$-actin followed by densitometry of the bands gave the results shown. (B) Effect of EGF (100 ng/ml) on HER2 phosphorylation in PC3 cells. The expression of B-tubulin was determined as a control. The results are representative of three experiments.

Thereafter, we evaluated by means of Western blot analysis and further densitometry whether the observed mRNAs translated into the corresponding proteins (Fig. 3). Again, the levels of expression of both HER2 and HER3 as well as those of HER2-P were higher in cancer cells as compared to normal cells. In fact, only a weak signal was detected for HER2-P whereas HER2 and HER3 were undetectable in normal RWPE1 cells in the conditions of the assay. The incubation of PC3 cells with EGF resulted in a higher extent of HER2 tyrosine phosphorylation.

Effect of VIP on HER2 and HER3 expression in prostate cancer PC 3 cells. The $\mathrm{G}_{\mathrm{s}}$ PCR agonist VIP induced the expression of mRNAs for HER2 and HER3 in PC3 cells as shown by means of both semiquantitative and real-time quantitative RT-PCR (Fig. 4). The effect was time-dependent and the highest responses to $100 \mathrm{nM}$ VIP were seen at 45 and $60 \mathrm{~min}$ of cell incubation for HER2 and HER3, respectively. The study of protein levels showed again a time-dependent stimulatory effect of VIP (Fig. 5). Cell incubation with $100 \mathrm{nM}$ VIP resulted in maximal responses of HER2 and HER3 protein expression at 120 and $60 \mathrm{~min}$, respectively. 
(A)

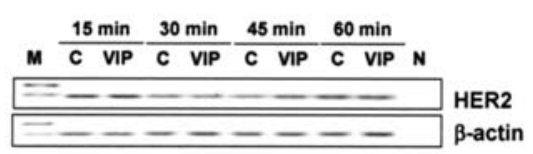

HER2

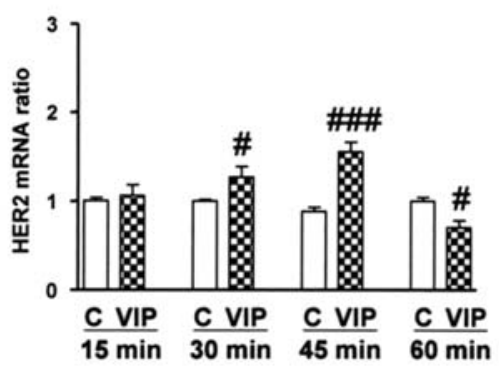

(B)

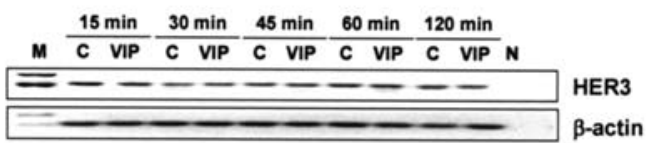

HER3

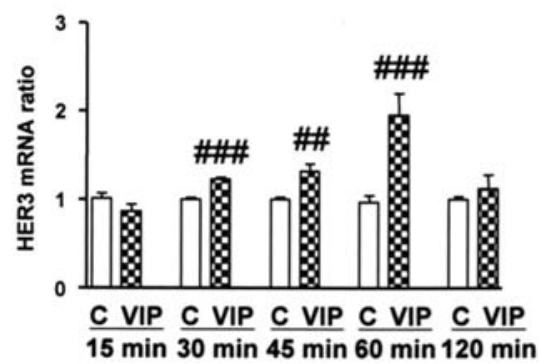

Figure 4. Time-dependent effect of VIP on the expression of mRNAs for HER2 (A) and HER3 (B) in PC3 androgen-independent prostate cancer cells. The cells were incubated in the absence or the presence of $100 \mathrm{nM}$ VIP for the indicated times. Upper panels: semiquantitative RT-PCR analysis for HER2, HER3, and B-actin mRNAs. M, 100-bp molecular DNA marker; N, negative control for PCR. The figure illustrates a representative assay of three independent experiments. Lower panels: real-time RT-PCR quantification of HER2 and HER3 mRNAs. Data in each bar are means $\pm \mathrm{SE}$. ${ }^{\#} \mathrm{P}<0.05$, ${ }^{\# \#} \mathrm{P}<0.01,{ }^{\# \#} \mathrm{P}<0.001$ versus control $(n=3)$.

HER2

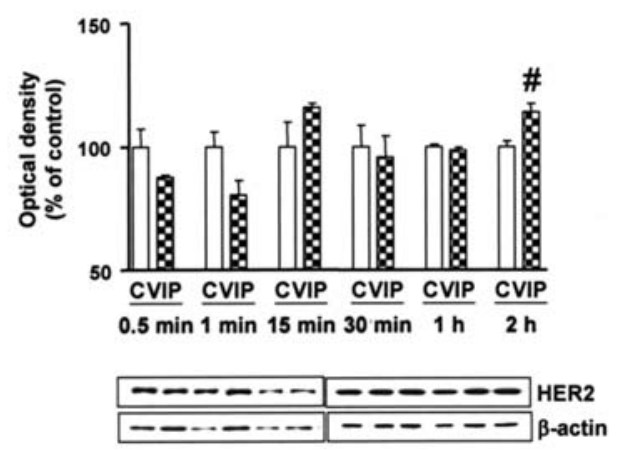

HER3

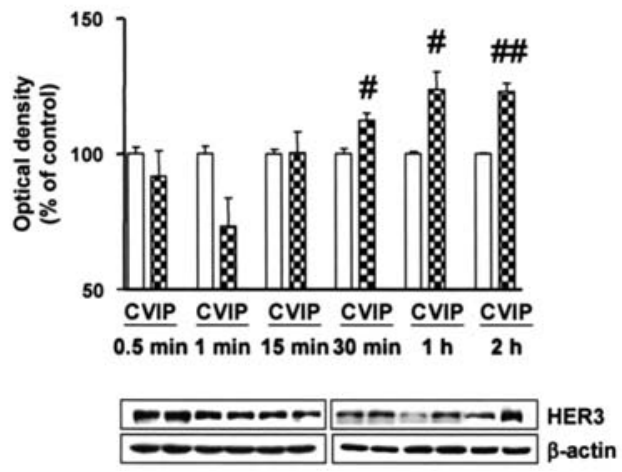

Figure 5. Time-dependent effect of VIP on the expression of HER2 (A) and HER3 (B) proteins in PC3 androgen-independent prostate cancer cells. The cells were incubated in the absence or the presence of $100 \mathrm{nM}$ VIP for the indicated times. After preparation of cell lysates, Western blotting using antibodies to HER proteins and $\beta$-actin followed by densitometry of the bands gave the results shown. A representative experiment is shown (upper panels). Data in each bar are the means $\pm \mathrm{SE}$. ${ }^{\#} \mathrm{P}<0.05,{ }^{\# \#} \mathrm{P}<0.01$ versus control $(\mathrm{n}=3)$.

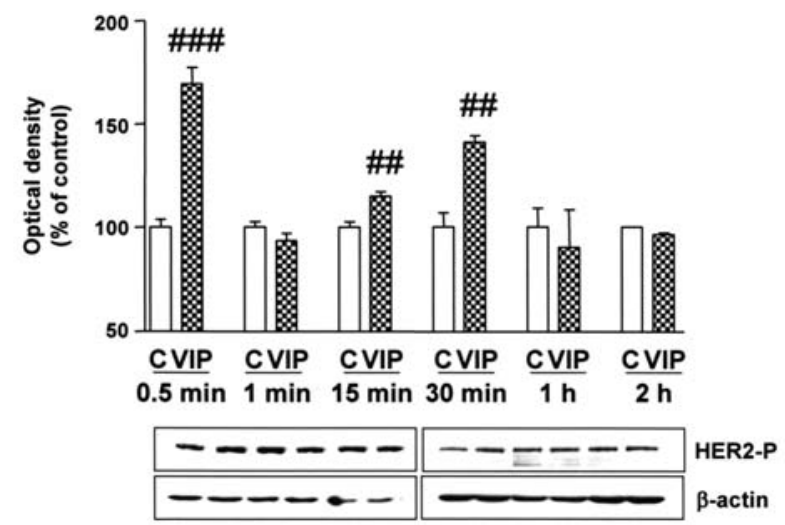

Figure 6. Time-dependent effect of VIP on the phosphorylation of HER2 protein in PC3 androgen-independent prostate cancer cells. The cells were incubated in the absence or the presence of $100 \mathrm{nM}$ VIP for the times indicated. After preparation of cell lysates, Western blotting using antibodies to HER2-P protein and $\beta$-actin followed by densitometry of the bands gave the results shown. A representative experiment is shown (upper panels). Data in each bar are the means $\pm \mathrm{SE} .{ }^{\# \#} \mathrm{P}<0.01,{ }^{\# \# \#} \mathrm{P}<0.001$ versus control $(\mathrm{n}=3)$.
HER2 transactivation by VIP in prostate cancer PC3 cells. In PC3 cells, VIP stimulated tyrosine phosphorylation of HER2 in a time-dependent fashion, as shown by cell incubation with $100 \mathrm{nM}$ VIP followed by Western blotting with antiHER2-P (Fig. 6). The effect of VIP was rapid in onset with maximal HER2 phosphorylation occurring within $30 \mathrm{sec}$ after the addition of the neuropeptide. A less prominent effect was observed between 15-30 min.

VIP acts mainly through adenylate cyclase/PKA activation but also via other signaling pathways (16-18). Thus, we determined which pathway is involved in the observed HER2 transactivation (Fig. 7). The early response to VIP was mediated by neuropeptide binding to VPAC receptors since cell preincubation for $30 \mathrm{~min}$ with the specific antagonist JV-1-53 (300 nM) completely blocked VIP-induced HER2 tyrosine phosphorylation. Moreover, PKA was involved in the transactivation mechanism since cell preincubation for 15 min with $10 \mu \mathrm{M}$ H89 (a specific inhibitor of PKA) nearly suppressed early HER2 phosphorylation in response to VIP. 


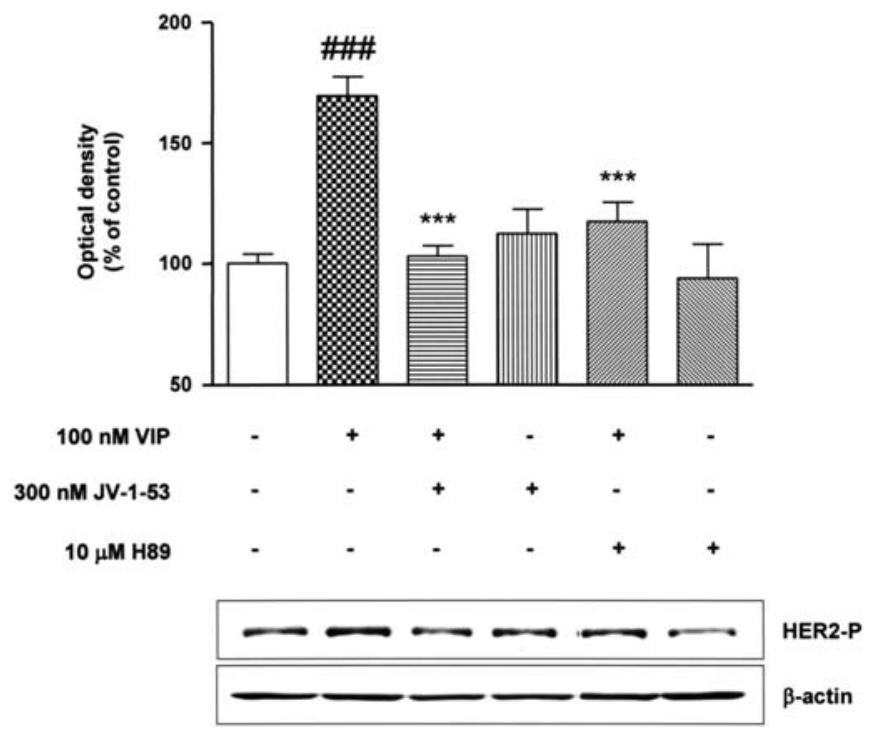

Figure 7. Inhibition of the stimulatory effect of VIP on the phosphorylation of HER2 protein in PC3 androgen-independent prostate cancer cells. The cells were preincubated either with the specific antagonist JV-1-53 (300 nM) for 30 min or with $10 \mu \mathrm{M} \mathrm{H} 89$ (a specific inhibitor of PKA) for $15 \mathrm{~min}$. Then, they were incubated in the absence or the presence of $100 \mathrm{nM}$ VIP for $0.5 \mathrm{~min}$. After preparation of cell lysates, Western blotting using antibodies to HER2-P protein and B-actin followed by densitometry of the bands gave the results shown. A representative experiment is shown (upper panels). Data in each bar are the means $\pm \mathrm{SE}$. ${ }^{\# \# /} \mathrm{P}<0.001$ versus control, ${ }^{* * * *} \mathrm{P}<0.001$ versus VIP $(n=3)$.

\section{Discussion}

The present study shows that VIP can modulate HER2 signaling within androgen-independent cancer PC3 cells by at least two mechanisms, increasing HER2 expression levels as well as HER2 tyrosine phosphorylation. These observations provide a framework to characterize the potential usefulness in prostate cancer therapy of combinations of available VIP receptor antagonists (19-21) and both monoclonal antibodies and tyrosine kinase inhibitors targeted to different members of the EGFR/HER family $(34,35)$.

Our results confirm previous data on the antimitogenic ability of some GHRH analogs endowed with VIP antagonistic ability in human prostate cancer cells $(21,39)$. The GHRH analogs JV-1-51, -52 and -53 nullified the autocrine/paracrine mitogenic stimuli of VIP. In addition, JV-1-51 and -52 exerted a significant antiproliferative effect when incubated alone with PC3 cells in the presence of serum. This difference between JV-1-51 and -52 as compared to JV-1-53 might be due to the mixed dual antagonistic properties of the two first peptide analogs that can bind to both VIP and GHRH receptors. Thus, the effect of JV-1-51 and -52 involved possibly additive responses whereas the action of JV-1-53 would have been elicited only through VIP receptors. Similar observations have been performed in prostate cancer LNCaP cells (39). The role of VIP in prostate cancer progression is based upon reports on cell lines and/or tissue specimens from prostatic origin showing overexpression of $\mathrm{VPAC}_{1}$ receptors (4) and VIP stimulation of cell proliferation (5), PSA secretion (6), neuroendocrine differentiation $(7,9)$, protection from apoptosis (9), VEGF expression $(7,8)$ and invasive capacity (9-11). Thus, the possible therapeutic benefits of VIP antagonists in human prostate cancer merit further investigation.

The HER family of tyrosine kinases is involved in mitogenic signaling pathways implicated in prostate cancer progression towards androgen independence, as shown by a number of studies on HER1 and HER2, and to a lesser extent on HER3 (30-33). HER2 has received special attention because it is aberrantly expressed in human prostate cancer tissue and cell lines, and its overexpression appears to involve transcriptional activation more than genomic amplification $(31,33,40,41)$. HER2 is the preferred receptor partner for HER1 and HER3 heterodimerization giving potent mitogenic signals $(28,29)$; it activates androgen receptor and has been linked to the clinical progression of ablation-resistant human prostate cancer $(32,33)$. Clinical trials are in progress in prostate cancer patients to test novel molecules that selectively interfere with HER2 activity $(34,35,42)$. Our study on HER2 and HER3 expression throughout prostate cancer progression showed increased mRNA levels that correlated with augmented protein levels for both receptors as well as the phosphorylated form of HER2 in tumoral $\mathrm{LNCaP}$ and PC3 cells as compared to normal, non-neoplastic RWPE-1 cells, in agreement with previous observations $(33,41)$. We used semiquantitative and real-time quantitative RT-PCR for mRNA, and Western blotting for protein measurements which did not detect any HER 2 or HER3 protein in RWPE-1 cells under the conditions of the test. This finding could be explained in terms of instability of mRNAs that prevented translation into the corresponding proteins in normal cells that, in any case, exhibited low levels of gene transcription (43). Some degree of mRNA instability may also exist for HER2 in LNCaP cells since the level of protein expression was lower than expected from the high level observed at mRNA expression. Treatment of PC3 cells with EGF resulted in the phosphorylation of EGF-based receptor dimers such as that including HER2 (i.e. the HER1/HER2 heterodimer) in concordance with previous findings $(22,35)$.

Increasing evidence exists that many substances may stimulate tyrosine phosphorylation of HER molecules leading to recruitment of associated signaling pathways. Thus, the HER family provides critical downstream elements for GPCRs, cytokine receptors, integrins, membrane depolarizing or stress-inducing agents $(44,45)$. Several GPCRs utilize HER transactivation to couple to the ERK/MAPK cascade by mechanisms involving $G_{s}, G_{q}$, PKA, protein kinase $C$ (PKC) and other signaling molecules $(45,46)$. This mechanism has been recently reported for VIP in colonic epithelial T84 cells (37). Our results show that this neuropeptide is linked to the HER system at least by two mechanisms since VIP induced the expression of specific genes for HER2 and HER3, but it also stimulated HER2 tyrosine phosphorylation.

VIP stimulated the synthesis of HER2 and HER3 mRNAs and proteins in long time frames compatible with the activation of the classical cyclic AMP/PKA dependent signal cascade and resulting in the expression of mRNA encoding HER2. A related model of activation by luteinizing hormone (LH) of its specific GPCR has been presented in which LH regulates EGF-like growth factors at the transcriptional level and at the level of processing of ligands to their mature forms with subsequent activation of HER/MAPK cascade (45). On the 
other hand, HER2 transactivation mediated by VIP occurred also in a time-dependent manner and developed rapidly since HER2 tyrosine phosphorylation was maximal within $30 \mathrm{sec}$ after addition of VIP. A similarly rapid and transient response has been observed for VIP/HER1 in colonic epithelial T84 cells (37). This fast response in PC3 cells was initiated by VIP binding to its receptors acting through PKA activation, as demonstrated by blocking of HER2 tyrosine phosphorylation with the specific antagonist JV-1-53 and the PKA inhibitor H89, respectively. This cross-talk of VIP mediating HER2 transactivation agrees with the known stimulatory effects of this neuropeptide upon the ERK/MAPK pathway $(4,9,17,18)$. Our observation of increased HER2-P levels at longer time periods (15-30 min) may conceivably be the result of the observed stimulatory activity of VIP on HER expression. This effect was not present in the study on colonic cells (37). Thus, VIP regulation of HER2 in PC3 cells appears to include rapid transactivation of pre-existing HER2 molecules followed by a slower induction of synthesis of new HER2 that can also be phosphorylated by a VIP-dependent mechanism.

Taken together, the reported data show the antiproliferative effects of GHRH-related VIP receptor antagonists and the stimulatory activity of VIP on HER2 expression and tyrosine phosphorylation together with the observed inhibition of this transactivation pattern by the specific VIP receptor antagonist JV-1-53 in prostate cancer cells. These features suggest that inhibition of growth of prostate cancer cells could be augmented by combining drugs acting upon VIP receptors $(19,21)$ with those targeted to HER $(27,34,35)$. These combinations could result in reduction of the optimal doses of both classes of agents. Thus, interfering with the cross-talk between VIP receptors and HER by blocking HER transactivation and/or expression could be of potential value in therapy of human prostate cancer.

\section{Acknowledgements}

This study was supported by grants from the Ministerio de Educación y Ciencia (SAF2004-4933), Comunidad Autónoma de Madrid (GR/SAL/0841/2004), and Fundación para la Investigación en Urología.

\section{References}

1. Jemal A, Siegel R, Ward E, Murray T, Xu J, Smigal C and Thun MJ: Cancer statistics, 2006. CA Cancer J Clin 56: 106-130, 2006.

2. Nagy A and Schally AV: Targeting of cytotoxic luteinizing hormone-analogs to breast, ovarian, endometrial, and prostate cancers. Biol Reprod 73: 851-859, 2005.

3. Schally AV, Comaru-Schally AM, Plonowski A, Nagy A, Halmos G and Rekasi Z: Peptide analogs in the therapy of prostate cancer. Prostate 45: 158-166, 2000.

4. Collado B, Carmena MJ, Sanchez-Chapado M, Ruiz-Villaespesa A, Bajo AM, Fernandez-Martinez AB, Varga JL, Schally AV and Prieto JC: Expression of vasoactive intestinal peptide and functional VIP receptors in human prostate cancer: antagonistic action of a growth-hormone-releasing hormone analog. Int $\mathrm{J}$ Oncol 26: 1629-1635, 2005.

5. Said SI: Vasoactive intestinal peptide. Biological role in health and disease. Trends Endocrinol Metab 2: 107-112, 1992.

6. Gkonos PJ, Ashby MH and Andrade AA: Vasoactive intestinal peptide stimulates prostate-specific antigen secretion by LNCaP prostate cancer cells. Regul Pept 65: 153-157, 1996.
7. Collado B, Gutiérrez-Cañas I, Rodríguez-Henche N, Prieto JC and Carmena MJ: Vasoactive intestinal peptide increases vascular growth factor expression and neuroendocrine differentiation in human prostate cancer LNCaP cells. Regul Pept 119: 69-75, 2004.

8. Collado B, Sánchez-Chapado M, Prieto JC and Carmena MJ: Hypoxia regulation of expression and angiogenic effects of vasoactive intestinal peptide (VIP) and VIP receptors in LNCaP prostate cancer cells. Mol Cell Endocrinol 249: 116-122, 2006.

9. Gutiérrez-Cañas I, Juarranz MG, Collado B, Rodríguez-Henche N, Chiloeches A, Prieto JC and Carmena MJ: Vasoactive intestinal peptide induces neuroendocrine differentiation in the $\mathrm{LNCaP}$ prostate cancer cell line through PKA, ERK and PI3K. Prostate 63: 44-55, 2005 .

10. Hoosein NM, Logothetis CJ and Chung IWK: Differential effects of peptide hormones, bombesin, vasoactive intestinal polypeptide and somatostatin analogue RC-160 on the invasive capacity of human prostatic carcinoma cells. J Urol 149: 1209-1213, 1993.

11. Sastry KS, Smith AJ, Karpova Y, Datta SR and Kulik G: Diverse antiapoptotic signaling pathways activated by vasoactive intestinal polypeptide, epidermal growth factor, and phosphatidylinositol 3-kinase in prostate cancer cells converge on BAD J Biol Chem 281: 20891-20901, 2006

12. Juarranz M, De Neef F and Robberecht P: Vasoactive intestinal polypeptide receptor $\mathrm{VPAC}_{1}$ subtype is predominant in rat prostate membranes. Prostate 1: 1-6, 1999.

13. Laburthe M and Couvineau A: Molecular pharmacology and structure of PACAP receptors for VIP and PACAP. Regul Pept 108: 165-173, 2002.

14. García-Fernández MO, Solano RM, Carmena MJ, Busto R, Bodega G, Ruíz-Villaespesa A and Sánchez-Chapado M: Expression of functional PACAP/VIP receptors in human prostate cancer and healthy tissue. Peptides 24: 893-902, 2003.

15. Gutiérrez-Cañas I, Rodríguez-Henche N, Bolaños O, Carmena MJ, Prieto JC and Juarranz MG: VIP and PACAP are autocrine factors that protect the androgen-independent prostate cancer cell line PC-3 from apoptosis induced by serum withdrawal. $\mathrm{Br}$ J Pharmacol 139: 1050-1058, 2003.

16. Cantley LC: The phosphoinositide 3-kinase pathway. Science 296: 1655-1657, 2002.

17. Richards J: New signaling pathways for hormones and cyclic adenosine 3',5'-monophosphate action in endocrine cells. Mol Endocrinol 15: 209-218, 2002.

18. Stork PJS and Schmitt JM: Crosstalk between cAMP and MAP kinase signaling in the regulation of cell proliferation. Trends Cell Biol 12: 258-266, 2002

19. Rekasi Z, Varga JL, Schally AV, Halmos G, Groot K and Czompoly T: Antagonistic actions of analogs related to growth hormone-releasing hormone (GHRH) on receptors for GHRH and vasoactive intestinal peptide on rat pituitary and pineal cells in vitro. Proc Natl Acad Sci USA 97: 1218-1223, 2000.

20. Varga JL, Schally AV, Csernus VJ, Zarandi M, Halmos G, Groot K and Rekasi Z: Synthesis and biological evaluation of antagonists of growth hormone-releasing hormone with high and protracted in vivo activities. Proc Natl Acad Sci USA 96: 692-697, 1999.

21. Plonowski A, Varga JL, Schally AV, Krupa M, Groot K and Halmos G: Inhibition of PC-3 human prostate cancers by analogs of growth-hormone-releasing hormone (GH-RH) endowed with vasoactive intestinal peptide (VIP) antagonistic activity. Int J Cancer 98: 624-629, 2002.

22. Anido J, Matar P, Albanell J, Guzmán M, Rojo F, Arribas J, Averbuch S and Baselga J: ZD1839, a specific epidermal growth factor receptor (EGFR) tyrosine kinase inhibitor, induces the formation of inactive EGFR/HER2 and EGFR/ HER3 heterodimers and prevents heregulin signaling in HER2-overexpressing breast cancer cells. Clin Cancer Res 9: 1274-1283, 2003

23. Yarden $Y$ and Sliwkowski MX: Untangling the ErbB signaling network. Nat Rev Mol Cell Biol 2: 127-137, 2001.

24. Freeman MR: HER2/HER3 heterodimers in prostate cancer: whither HER1/EGFR? Cancer Cell 6: 427-428, 2004.

25. Alroy I and Yarden Y: The ErbB signaling network in embryogenesis and oncogenesis: signal diversification through combinatorial ligand-receptor interactions. FEBS Lett 410: 83-86, 1997.

26. El Sheik SS, Domin J, Abel P, Stamp G and Lalani EN: Phosphorylation of both EGFR and ErbB2 is a reliable predictor of prostate cancer cell proliferation in response to EGF. Neoplasia 6: 846-853, 2004 
27. Robert D and Mass MD: The HER receptor family: a rich target for therapeutic development. Int J Radiat Oncol Biol Phys 58: 932-940, 2004

28. Pinkas-Kramarski R, Soussan L, Waterman H, Levkowitz G, Alroy I, Klapper L, Lavi S, Seger R, Ratzkin BJ, Sela M and Yarden Y: Diversification of Neu differentiation factor and epidermal growth factor signaling by combinatorial receptor interactions. EMBO J 15: 2452-2467, 1996.

29. Yen L, Benlimame N, Nie ZR, Xiao D, Wang T, Al Moustafa AE, Esumi H, Milanini J, Hynes NE, Pages G and Alaoui-Jamali MA: Differential regulation of tumor angiogenesis by distinct ErbB homo- and heterodimers. Mol Cell Biol 13: 4044-4049, 2002.

30. Di Lorenzo G, Tortora G, D'Armiento FP, De Laurentiis M, Placido SD, Catalano G, Bianco AR and Ciardiello F: Expression of epidermal growth factor receptor correlates with disease relapse and progression to androgen-independence in human prostate cancer. Clin Cancer Res 8: 3438-3444, 2002.

31. Carles J, Lloreta J, Salido M, Font A, Suárez M, Baena V, Nogué M, Doménech M and Fabregat X: Her-2/neu expression in prostate cancer: a dynamic process? Clin Cancer Res 10: 4742-4745, 2004.

32. Wen Y, Hu M, Makino K, Spohn B, Bartholomeusz G and Yan DH: HER-2/neu promotes androgen-independent survival and growth of prostate cancer cells through the Akt pathway. Cancer Res 60: 6841-6845, 2000.

33. Berger R, Lin DI, Nieto M, Sicinska E, Garraway LA, Adams H, Signoretti S, Hahn WC and Loda M: Androgen-dependent regulation of Her-2/neu in prostate cancer cells. Cancer Res 66: 5723-5728, 2006.

34. Formento P, Hannoun-Levi JM, Fischel JL, Magné N, Etienne-Grimaldi MC and Milano G: Dual HER1-2 targeting of hormone-refractory prostate cancer by ZD1389 and trastuzumab. Eur J Cancer 40: 2837-2844, 2004.

35. Bellezza I, Bracarda S, Caserta C and Minelli A: Targeting of EGFR tyrosine kinase by ZD1839 ('Iressa') in androgenresponsive prostate cancer in vitro. Mol Genet Metab 88: 114-122, 2006

36. He H, Levitzki A, Zhu HJ, Walker F, Burgess A and Maruta H: Platelet-derived growth factor requires epidermal growth factor receptor to activate p21-activated kinase family kinases. J Biol Chem 276: 26741-26744, 2001.
37. Bertelsen L, Barrett K and Keely S: $\mathrm{G}_{\mathrm{s}}$ protein-coupled receptor agonist induce transactivation of the epidermal growth factor receptor in T84 cells. J Biol Chem 279: 6271-6279, 2004.

38. Chang JT, Chen IH, Liao CT, Wang HM, Hsu YM, Hung KF, Lin CJ, Hsieh LL and Cheng AJ: A reverse transcription comparative real-time PCR method for quantitative detection of angiogenic growth factors in head and neck cancer patients. Clin Biochem 35: 591-596, 2002.

39. Rekasi Z, Varga JL, Schally AV, Halmos G, Armatis P, Groot K and Czompoly T: Antagonists of growth hormone-releasing hormone and vasoactive intestinal peptide inhibit tumor proliferation by different mechanisms: evidence from in vitro studies on human prostatic and pancreatic cancers. Endocrinology 141: 2120-2128, 2000.

40. Brys M, Stawinska M, Foksinski M, Barecki A, Zydec C, Miekos E and Krajewska WM: Androgen receptor versus erbB-1 and erbB-2 expression in human prostate neoplasms. Oncol Rep 11: 219-224, 2004.

41. Di Lorenzo G, Autorino R, De Laurentiis M, Cindolo L, D'Armiento M, Bianco AR and De Placido S: HER-2/neu receptor in prostate cancer development and progression to androgen independence. Tumori 90: 163-170, 2004.

42. Rau KM, Kang HY, Cha TL, Miller SA and Hung MC: The mechanisms and managements of hormone-therapy resistance in breast and prostate cancers. Endocr Rel Cancer 12: 511-532, 2005.

43. Kuwahara I, Lillehoj EP, Lu W, Singh IS, Isohama Y, Miyata T and Kim KC: Neutrophil elastase induces IL-8 gene transcription and protein release through $\mathrm{p} 38 / \mathrm{NF}-\mathrm{\kappa B}$ activation via EGFR transactivation in a lung epithelial cell line. Am J Physiol Lung Cell Mol Physiol 291: L407-L416, 2006.

44. Leserer M, Gschwind A and Ulrich A: Epidermal growth factor receptor signal transactivation. IUBMB Life 49: 405-409, 2000 .

45. Hsieh M and Conti M: G-protein-coupled receptor signaling and the EGF network in endocrine systems. Trends Endocrinol Metab 16: 320-326, 2005.

46. Wetzker R and Bohmer FD: Transactivation joins multiple tracks to the ERK/MAPK cascade. Nat Rev Mol Cell Biol 4: 651-657, 2003. 